\title{
Historicizing and Contextualizing the Discourse on African International Law and A Concise Overview of the Pacific Settlement of the Cameroon-Nigeria Bakassi Peninsula Dispute*
}

\author{
E. Ike Udogu \\ Professor and President, Association of Third World Studies (ATWS) \\ Department of Political Science and Criminal Justice, Old Belk Library, \\ Appalachian State University, Boone, NC 28608-2107 \\ udoguei@appstate.edu
}

\begin{abstract}
For the past 50 years or so, the media and intellectual discourses on African politics have general portrayed the continent as being in perpetual turmoil. The causes of such conflicts have been related, but not limited, to the outcome of the Berlin Conference of 1884-85 in which some of the European powers carved up the region in a zigzag fashion with little or no concern for the ethnic complexions of the societies. The result of this policy in post-colonial and independent Africa has been disastrous for much of the continent with numerous civil wars and cross border clashes between African states. The use of arms struggle to resolve border conflicts is now seen as counter productive to the vision of African unity and transformation in the millennium as first articulated by the Organization of African Unity and now championed by the African Union the successor to the OAU. This study brings into the limelight the extent to which African states are increasingly relying on international law, the AU and the Good Offices of the UN and its various agencies to resolve international boundary conflicts. It also historicized the development of international law in Africa and discussed as a case study the impressive pacific settlement of the explosive border dispute between Cameroon and Nigeria to illustrate its importance as a model for Africa.
\end{abstract}

\section{Keywords}

African international law; African Union; arbitration; Berlin Conference of 1884-85; BritishGerman Treaty of 1913; Cameroon-Nigeria Bakassi Peninsula Dispute; conciliation; effectivites; mediation; organization of African unity

\section{Introduction}

Historians are generally quick to remind us that we must first understand the social, political and religious development of a polity in the past in order to 
comprehend the political and social character of the present and future of a society; and political historians would further argue that the character of a political system at any given moment in time is generally determined by the political culture of that entity. The central purpose of this paper rests on the following: 1. A brief allusion to, and narration of, Africa's historical practice and appreciation of international law in the pre-colonial period; 2 . An accentuation on Africa's adoption, adaptation and practice of international law at the significant epoch following the continent's emancipation from a political science, rather than a juridical, epistemology, and 3. An illustration of the impressive pacific settlement of a highly combustible issue over the oil-rich Bakassi peninsula between Cameroon and Nigeria using the instrument of international law and not major arms struggle.

In truth, this discussion is unique to the extent that it contends that African international law did exist during pre-colonial Africa (e.g., the "law of interethnic war"). There is little wonder, then, that Lante Wallace-Bruce explained eloquently the nature of African international law in the pre-colonial era by asserting inter alia, that during the ancient Mali Empire, statesmen were exchanged between Mali and Morocco. In the sixteenth century, the Kingdom of Benin sent an ambassador to Portugal, and Bornu exchanged ambassadors with Turkey. There were also pre-colonial commercial and trading treaties on the East African coast. Thus, it would appear that the main effect of colonialism on the state organization in Africa was to interrupt the sovereignty of the network of indigenous states that have previously been flourishing in the continent (Wallace-Bruce 1985, pp. 575-602). Thus, it is paradoxical to note that the traditional concept of "African international law" became inconsequential following the conquest of the continent by Western powers. This colonization led to the diminution of African genre of epistemology because it was subsumed by the introduction of Eurocentric "theory of the nature, the sources, and limits, of knowledge" in the continent.

In any case, when I first took on this project, it was my intention to investigate "African International Law" within the global context. But, I was quick to realize that what might be referred to as African international law is the same law which was practiced by Africa's erstwhile colonial rulers in the region. And as J.L. Brierly has noted, the law of nations "had its origin among a few kindred nations of Western Europe which, despite the religious schism of the sixteenth century, had all and were all conscious of having a common background in the Christian religion and in the civilization of Greece and Rome (Brierly 1963, p. 41)."

In general, as a result of the European colonial influence in Africa relatively few studies have been undertaken on African international law (Wallace-Bruce 1985; 
Pakinson 1975, pp. 11-26). In spite of that, however, some prominent African scholars, such as T.O. Elias writing in Africa and the Development of International Law, have noted, among other factors, some of the vital contributions made by Africa to the character of international law. In fact, he noted, historically, that:

From the time that Almoravids and the Tauregs overran the old Empire of Ghana in 1087 till the assumption of the kingship in Mali by Mansa Musa, of Timbuktu by Askia the Great, and the subsequent potentates of the old kingdom of Songhai, Walata, Sosso, and Jenne, there were regular exchanges of ambassadors between the African courts and those of Spain, Egypt, and most of Asia... Moreover, the pre-colonial European Africa was not all chaos and "inter-tribal" feud. Agreements were often entered into by one king or paramount chief with another as much as to regulate their external relations as to promote territorial advancement (Elias 1972, pp. 42-44; July 1992, pp. 4, 61-64; Bovill 1958, pp.62-63, 124-129).

And, as was to be expected, the study of the foregoing genre of international relations and law was subsumed by European colonialism and its subsequently imposed genre of knowledge and epistemology on its subjects. Thus, it was only much after independence that the teaching of international law in African universities and colleges was encouraged and taught. One could argue that the teaching of international law at universities and colleges today exemplifies a recognition and acceptance by African states of its role and significance in international politics and, in general, for its greater comprehension within the region's cultural and historical context.

Relatively speaking, the concept of international law in Africa has not yet attained the same degree of clarity as its European counterpart. One reason for this is that most of the newly emergent African states in the 1960s and after saw independence as the means for improving the socio-economic conditions of their populations and thus tended to be less concerned about international law. Moreover, it must be added that in some cases African states were just plainly apprehensive, if not xenophobic, of international law. Some argued that it was responsible in part for their political fate as exemplified by the outcome of the Berlin Conference of 1884-85 (attended by representatives of Great Britain, Austria-Hungary, France, Germany, Russia, USA, Portugal, Denmark, Spain, Italy, the Netherlands, Sweden, Belgium and Turkey), that carved up the African continent into European colonies and protectorates (Louis et al., 1971, pp. 193-194).

Undeniably, it might be foolhardy to theoretically apply the elements and tenets of international law - particularly that international legal order which is practiced in the Occident globally. Thus, it was within this context that 
Arnulf B. Lorca noted with lucidity in the Latin American case that when the whole complex package of international law and practices is

posed in relation to contemporary Latin America, these questions become unexpectedly tricky, since the discipline of international law does not offer to international lawyers situated at the periphery adequate analytical tools for understanding the meaning and uses of international law in their own context [i.e. within the background of their cultural and historical specificity] ... international law's structure of ideas, historical narratives, professional sensibilities, and modes of argumentation have made international lawyers accept the idea of European origin and outward expansion of international law... [indeed],... international law can have different meanings in various geopolitical locations (Lorca 2006, p. 283).

In a robust discourse on the theory of international law extracted from the European Journal of International Law, a major problematic of universalizing the interpretation, practice and application of international legal order was brought to the fore. This is especially in the areas of knowledge, international law, liberal theory and political interest. Indeed, it was noted that:

There is an additional and elusive feature to this process which is essential to the formalism and abstraction of law, to the ambition to create an order beyond political interest. Knowledge, and therefore legal knowledge, does not relate to ideas and facts themselves, but, a (representational) meaning which might be discovered in their name. Knowledge is a social product. So, knowledge cannot only be established through a knowledge-producing process in a meaning-generative (name-giving) consensus in the State. In this context law, as an ideal, is that which has been consensually produced, through the state, by which consists of complete and logically organized wholes, beyond the subjectivity of morality and politics. This is the ideal [situation] which legal method/s sets out to attain. It is fundamentally flawed because full consent is never there and so there is simply no sense in the attempt to attain objectivity (Critical International Law: Recent Trends in the Theory of International Law, The Debt of International Law to Liberal Political Theory, 1999, p. 3; Kennedy 1987; MacIntyre 1985).

It is against the backdrop of the foregoing concise theoretical peculiarities and complexities that this disquisition addresses concisely the practice of African International Law under the following rubrics:

- The Organization of African Unity (now the African Union since 2002) and International Law.

- The Issue of African Legal Order.

- The Principle of Sovereign Equality of all States and its Implications for International Relations/Law.

- The Settlement of Inter-African Dispute. 
- The Question of Ethnic and Territorial Dispute.

- Negotiation, Conciliation and Arbitration under the sponsorship of the UN: The Cameroon-Nigeria Bakassi Peninsula Case.

\section{The Organization of African Unity and International Law}

The Organization of African Unity, that will be used synonymously with its contemporary nomenclature, African Union (AU) in this text, was born in Addis Ababa, Ethiopia, on May 25, 1963, out of historic necessity and despite a welter of conflicting political ideas and interests (Legum 1975, p. 208). Whether the signing of the OAU Charter (by leaders of the 18 African countries present in the founding) will become a stepping stone toward an eventual United States of Africa as many pan-Africanists desired or remain essentially a skeletal framework for a loose and voluntary association of sovereign states, even within the context of the contemporary African Union, only time will tell. But at the very least the move was significant in that the heads of state were ready to take a forward step in translating the widely proclaimed goal of African unity into a tangible form of organization, however tenuous and divided its organs remained because of clashing interests. The OAU was regarded as a regional arrangement in keeping with Chapter VIII of the United Nations Charter. Chapter VIII, Article 52 affirms that:

1. Nothing in the present charter precludes the existence of regional arrangements or agencies for dealing with such matters relating to the maintenance of international peace and security as are appropriate for the regional action, provided that such arrangements or agencies and their activities are consistent with the Purposes and Principles of the United Nations.

2. The Members of the United Nations entering into such arrangements or constituting such agencies shall make every effort to achieve pacific settlement of local disputes through such regional arrangements or by such regional agencies before referring them to the Security Council.

3. The Security Council shall encourage the development of pacific settlement of local disputes through such regional arrangements or by such regional agencies either on the initiative of the states concerned or by reference from the Security Council.

4. This Article in no way impairs the application of Articles 34 and 35.

Article 34 states that: The Security Council may investigate any dispute, or any situation which might lead to international friction or give rise to a 
dispute, in order to determine whether the continuance of the dispute or situation is likely to endanger the maintenance of international peace and security. Article 35, inter alia, states that: Any member of the UN may bring any dispute or any situation of the nature referred to in Article 34 to the attention of the Security Council or the General Assembly. Several years have passed since the Organization of African Unity was established. Historically speaking, this period is relatively short and perhaps not long enough to draw a more or less valid opinion on the activities of the institution and the place it holds in relation to the positive law of nations. But for anybody concerned with inter-state cooperation (e.g., Cameroon and Nigeria), any regional organization (e.g., ECOWAS, SADC, etc.) emerging from the decolonization process and working to maintain international peace and security is deserving of particular attention and requires periodic review. It is true that such bodies play an especially momentous role in international life, both concerning the problem of war and peace and the peaceful settlement of disputations.

Let it suffice to say here that various sources of information are of limited help in attempting a scientific definition of the legal intercourse between African states and thus, it is not always possible to be as clear as one would like on a legal development process in Africa; indeed, more than once, comments have to be merely approximation and conjectural. Added to this complexity is the fact that any appraisal of international practice must first be undertaken from the point of view of (national/international) legislation but without ignoring the social and political specificities of a society, since any legal order that did not take into account the political realities of its context may be merely academic, insubstantial, and removed from life. My approach to this logic, therefore, is to deal with the character of some of the legal practices that are at best subjective and operational - even heuristic.

It might be wrong to play down the role and contributions of individual states to the establishment of the provisions of international law. Such contributions, it must be added, take the form of a great number of bilateral and, in some cases, multilateral treaties concluded between African states and with non-African countries. Arguably, it was through and within the OAU that such a contribution was most obvious, fruitful, and most highly institutionalized. OAU (and AU) is a conspicuous proof of the legal solidarity of its more than 50 member nations, and increasingly its drafting of the regulations of the law of nations can be compared to a kind of work of "codification" in the loose sense of the word.

In more than one respect, the contribution of Africa to the universal legal order is relatively modest but will continue to grow particularly within the constitutive African Union in the area of pacific settlement of border disputes 
since the zigzag boundaries constructed at the Berlin Conference may increase irredentist wars in the continent. Be that as it may in explaining the reason for the continent's moderate contribution to the law of nations some scholars noted that the European metropolitan powers were the exclusive or the active parties during the colonial period who stressed the idea that only sovereign states were at any time the actors of customary international law. It is further observed that no matter how one visualizes the situation in Africa that:

The drum of international legal relations was being played out, so far as Africa [was] concerned, by European Governments among themselves in regard to economic, technical and cultural matters. Customary international law was developing in many respects as a result of the continuous changes taking place in the continent but the African dependencies were spectators at the game (Elias 1972, p. 21).

Nonetheless, it must not be forgotten that European powers have taken centuries to forge a certain number of regulations on the "positive law of nations." Initially, it was somewhat true that at the Addis Ababa Conference the heads of state and government took relatively little note of the effect of international law on the new organization and its relations with the United Nations. The text of the Charter holds few direct references to international law. It might be that independent Africa was mistrustful of European interpretation of the precepts of international law since it felt that before it became independent, the international law then in force was "designed to legalize the privileges of European states [particularly in the governance of their territorial claims] (BoutorsGhali 1972, p. 5)." Thus, at Addis Ababa, only those principles of the law of nations directly concerning Africa were referred to; and among those, some with an immediate political impact on the African continent were accepted by the new states. For example, Article 3 of the OAU Charter states both the seven principles that deal with essential African political problems, and Africa's relations with the external world. Some of the principles also deal with international politics. These principles are as follows:

1. The sovereign equality of all member states.

2. Noninterference in the internal affairs of states (as in Art. 2, paragraphs 4 and 7, of the UN Charter).

3. Respect of the sovereignty and territorial integrity of every state and its inalienable right to independent existence.

4. The peaceful settlement of dispute through negotiations, mediation, conciliation or arbitration.

5. Condemnation without reservation of political assassination and subversive activities carried on by neighboring states, or all other states. 
6. Absolute devotion to the cause of total liberation of African territory not yet independent.

7. Affirmation of a policy of nonalignment in respect of all political blocs (Ajala 1973, pp. 370-371; OAU Charter 1982, p. 9).

Article 6 of the OAU Charter also states that "the member states pledge themselves to observe scrupulously the principles enumerated in Article III of the present charter." Besides these tenets and concerns, there were other vital legal problems concerning the continent, for example, the issue of African legal order.

\section{The Issue of African Legal Order}

The crafting of the principles of international law by OAU raised an issue of effectiveness of the Organization of African Unity's legal system. This was the case given OAU's inchoate status and adjustment to the character of the international law in practice in the Occident from which the drafters borrowed. Historically, under the system of the League of Nations and that of the United Nations, the functioning of international bodies has always left much to be desired. For instance, sanction procedures have always been and still remain unsatisfactory as exemplified by the League of Nations failure in its sanctions against Italian aggression in Ethiopia. Moreover, differences among the great powers of the Security Council in the United Nations have sometimes rendered the UN inoperative, and the organization's many resolutions generally fruitless. Despite such serious drawbacks, however, some regulations of international law such as the Universal Declaration of Human Rights have gradually acquired an existence independent of any purely national institutional context - particularly appeals to national sovereignty, even cultural relativism by states as rationales for violating human rights provisions (Udogu 2003, pp. 115-118).

The fact that Africa still manifests some mistrust of international jurisdiction or of arbitration procedures founded on the strict respect of law is not directly related to the problem of organs, procedures, or sanctions but the anomalies in its application to African issues, as for example, the vexing question of decolonization. While expressing reservations on the legal formulae of arbitration or those of the International Court of Justice, Africans have resolved to settle their disputes using procedures which, while lacking in institutional rigidity, help to regulate certain types of interstate relationships (El-Ayouty 1975, p. 83).

Further, the application of OAU's decisions within the continent itself very frequently suffered from lack of sanctions (El-Ayouty 1975, p. 84). Although 
the organization is founded on legal principles, it has drawn up some of its own culturally specific legal instruments and created a practice. But it is obvious that its activities were often dominated by political problems such as the Western Sahara question between Morocco and the Polisaro. And, it must be quickly added here that unity is not necessarily synonymous with uniformity.

\section{The Principles of Sovereign Equality and Its Implications for International Relations/Law}

The principle of the sovereign equality of states was more strictly formulated in Article 3, paragraph 1 (that affirmed the sovereign equality of all Member states), and Article 5 (all Member states shall enjoy equal rights and have equal duties) of the OAU Charter than in the United Nations specialized agencies or in the context of regional groupings or associations such as the Organization of American States or the European Economic Community.

Although the assumption around the current world order rests on a legal base of egalitarianism (e.g., one nation one vote), it is politically - even logically - still in-egalitarian and multidimensional. It is made up of sovereign states with highly variable political and economic clout within the international community (for example, Egypt and Liberia). These sovereignties play differential roles depending on their real or putative power in the formulations of the regulations of international law.

Contrary to the United Nations, the OAU system had no Security Council with particular powers in matters of war and peace, and it theoretically gave no privilege position to the "great powers" of Africa. It attempted to avoid the formation of any kind of hegemony (either de facto or de jure), and did not base itself on the model of Organization of American States where the U.S. played and continued to play a hegemonic role (notwithstanding the role of Nigeria in ECOWAS, a sub-regional grouping). It also avoided the weighted voting formulae presently in force in some specialized agencies, for instance, International Monetary Fund, International Financial Corporation and the European Economic Community. These organizations established differential voting rights. The OAU formula remained "one state, one vote," and the highest organ of the OAU was the Conference of Heads of State and Government, with a two-third majority required to pass a measure. This arrangement was particularly striking when one recalls, for instance, that the population of Botswana was 971,027, Equatorial Guinea 304,000, Seychelles 65,139, and Nigeria 91,085,000 (Banks 1977, pp. 60, 155, 461, 373). Despite the anomalous or uneven populations, they were and are euphemistically viewed as "equals" in the OAU and its successor, the African Union. 


\section{The Settlement of Inter-African Disputes: the Commission on Mediation, Conciliation and Arbitration under the OAU Charter}

Before the Addis Ababa Charter, African states had no effective institutionalized mechanism for the peaceful settlement of disputes. With the coming of independence, the uncertain nature of African territorial boundaries led to intricate and difficult boundary disputes. Examples of disputes were SomaliaKenya (Ajala 1973, pp. 148-156) and Ghana-Upper Volta, now Burkina Faso (Meyers 1974, p. 357), to name a few. Efforts to settle such disputes by diplomacy were not always successful and often had the disconcerting tendency of erupting into armed conflicts (Smith 1987, p. 37). The new African states were troubled by boundary problems inherited from the era of European colonial administration, but to mitigate inter-state conflicts many of them had since independence entered into a number of international conventions and arrangements inter se (especially in the economic, commercial and cultural fields).

At the Addis Ababa conference the African leaders urged the importance of ensuring African peace and harmony, and called for the formal erection of machinery for the settlement of disputes. In response to this appeal, the Organization of African Unity in its Charter, "pledged members to settle all disputes among themselves by peaceful means (OAU Charter \& Rule of Procedure 1982, p. 13)," and in Article VII (4) established a Commission of Mediation, Conciliation and Arbitration - the constitution and powers of which were defined by a protocol signed in Cairo on July 21, 1964 (Protocol of the Commission on Mediation, Conciliation, and Arbitration, 1964, pp. 1116-1124).

Article XII of part II of the Protocol provides that the Commission shall have jurisdiction over disputes between states. The idea is not only to enable member states to avail themselves of the services of the Commission, but also to make possible for non-member states wishing so, to use the resources of the Commission. The members of the Commission, when engaged in the business of the Commission shall enjoy diplomatic privileges and immunities (Protocol of the Commission on Mediation, Conciliation and Arbitration, 1964).

\section{Mediation}

Article XX of Part III of the Protocol provides that when a dispute between member states is referred to the Commission for mediation, the President shall with the consent of parties appoint one or more members of the Commission to mediate the dispute. The role of the mediator is confined to reconciling the views and claims of the parties. If the means of reconciliation 
proposed by mediators are accepted, they shall become the bases of protocol of arrangement between the parties.

The Protocol follows international practice concerning the nature of mediation. It is said to consist of the direct conduct of negotiation between the parties at issue on the basis of proposals made by the mediator.

\section{Conciliation}

The OAU Protocol stipulates that a request for the settlement of a dispute by means of conciliation may be submitted to the Commission by means of a petition addressed to the President by one of the parties to the controversy. The petition is to include a summary explanation on the grounds of the dispute. The formation of the Board of Conciliations is a relatively simple exercise. The President, in agreement with the parties, appoints three members from among members of the Commission; while one each is appointed by the parties. No two members of the Board are to be nationals of the same nation-state.

The function of the Board of Conciliations is to explain the issues in dispute and to attempt to bring about an arrangement between the parties upon mutually acceptable terms. At the conclusion of its proceedings, the Board is to draw up a report stating the terms of the agreement, if any, between the parties and its own recommendations for settlement. The report, which must be communicated to the parties without delay, may be published only with their consent.

\section{Arbitration}

Under Article XXVII of Part V of the Protocol, if the parties to a dispute that has been brought before the Commission agree to resort to arbitration, an arbitral tribunal would be established by the Commission. At least two members of the arbitration tribunal are to have legal qualification. Since arbitration is a legal procedure, it is recommended that all members should have legal qualifications or be competent in international law. Some scholars have argued that the employment of arbitration in settling international disputes by an international agency implies two conditions: (1) That the members of the international agency be persons learned in the law and competent to apply the judicial process in the rendering of legal decisions; and (2) that the agency be competent to settle international disputes by international law (Tucker 1966, p. 377).

The Protocol requires the parties to conclude arbitration Compromis undertaking to accept the decisions as legally binding and defining the power to adjudicate ex aequo et bono. (That is whenever parties to a dispute agree to have 
recourse to arbitration the Protocol provides that such agreement must be regarded as submission in good faith to the award of the arbitral tribunal). Unless the disputants provide otherwise, the law applicable is that according to treaties made between the parties, international law, the Charter of the OAU, the Charter of the United Nations, and that the actors agree, ex aequo et bono.

\section{The Question of Ethnic and Territorial Disputes}

At the conference establishing OAU in Addis Ababa several heads of state and governments stressed the complexity of the ethnic problems in the area. The continent is inhabited by a mosaic of peoples and ethnic groups whose particularities are only very slowly disappearing in light of their affinity to a nation-state that is taking shape especially among lawmakers and members of the informed public. There are numerous ethnic groups with different languages whose historical and cultural links have not always been harmonious. At the risk of disintegrating, the custodians of power of most African states find themselves struggling to transcend ethnic differences in order to forge a national consciousness, which is essential for the atomization of any multiethnic/multi-lingual state. Politically, many African countries are too fragile and, economically, too dependent on the Occident to undertake the process of agglutination of their multi-ethnic "mini-sovereignties." But, at Addis Ababa the African leaders declared a resolve to safeguard and consolidate the territorial integrity of their states (as in Art. 2, Section C, Art. 3 Section 3 and the 7 points of the preamble of the OAU Charter). The 1962 Conference of Heads of state and government which met in Cairo on July 17-21 pointed out that frontier problems are a serious permanent factor of disagreement among African states. It further noted that the frontiers of African states on the day of their independence constituted a tangible reality, and solemnly declared that all member states undertake to respect the frontiers existing at the time of their independence in order to eschew irredentist conflicts (e.g., Somalis in Ethiopia, Kenya and Somalia).

The originality of this position and the interest it holds for doctrinal development of positive international law are complex. Until this declaration, international law had not fully succeeded in clearly formulating principles that should prevail in respect of state's claims to territory; if the doctrine is inclined toward the thesis of transmissibility of frontiers established by virtue of international treaties, it would be difficult to apply this principle to frontiers resulting from old administrative divisions made by the colonial powers (e.g., Cameroon-Nigeria Bakassi peninsula dispute). 
The principle Uti Posseditis is used to designate a boundary at the point where de facto colonial boundary lines existed in terms of effective control (Jacobini, 1968, p. 96). In the case of Africa, it was a matter of essentially confirming colonial interstate boundaries. Even this arrangement has in a number of cases pitted one African state against another, such that some nations have shown dissatisfaction with this framework. A good case in point is Libya's claim to parts of northern Chad.

The OAU has had problems with implementing and enforcing the rules stipulated for solving Africa's disputes in part because it lacked the tools for doing so, and sometimes because of ideological incongruence among the trustees of government anchored in the erstwhile East-West conflict. Moreover, the difficulty was not due to lack of effort but because of the sometimes fierce resistance by leaders who fear that their position of privilege could be greatly curtailed. Such was the case with respect to the discourse on the need for instant formation of one African government by Kwame Nkrumah and those like Jomo Kenyatta who resisted the concept within the Pan-African Movement (Lumumba-Kasongo 2004). Added to this dimension is leaders' sense of ethno/nationalism. Some political actors feared that if they appeared to kowtow to OAU protocols intended to resolve territorial dispute, for example, they could lose support from their constituency. And, if the newly established OAU was, and is, unable to enforce the rules and regulations contained in its Charter (as for example, its own Commission for Mediation, Conciliation and Arbitration) who else could but the United Nations? Indeed, it is the UN whose decisions could be backed by the power of the Security Council and its Secretary-General. Arguably, it was to this end that a territorial dispute between Cameroon and Nigeria that could have been solved by the OAU was transmitted to the UN. It is against the backdrop of the foregoing analytic suppositions in African politics, international relations and law that the case study of the Cameroon-Nigeria territorial dispute is crisply examined in the proceeding analyses.

\section{Brief Historical Background}

An excellent and terse narration of the peculiar character of the historical context and content within which the political and legal imbroglio of the Bakassi Peninsula case between Cameroon and Nigeria could be visualized was provided by Assisi Asobie. In fact, the problem over the disputed area flows from a mix of seemingly obvious antinomies. First, there is the conflict between the forces of modernity and traditionalism. In other words, the pre-colonial history of the ancient kingdom of Calabar was seen as clashing with the 
post-colonial reality of contemporary Nigeria and Cameroon. Second, there is the confusion arising from the interpretation of the cartographic presentation and cultural reality on the ground. Third, there is the clash between the dictates of complex international law and the complicated life of a people trying to provide a living for themselves and the extended family system, inter alia (Asobie, Nigeria-Cameroun and the Unending Conflict Over Bakassi, Nd.).

The incongruity one witnesses in this case is a perplexing one. In the precolonial era, Bakassi was under the control of the king of Calabar that, in 1914, became part of modern Nigeria following the amalgamation of Northern and Southern protectorates by the British. Technically, by treaty of September 10, 1884, the Obong or king of Calabar placed his kingdom under the protection of the British. However, in the colonial policy of divide and rule, the British conceded the area (first) to the Germans. It was later placed under the League of Nations mandate following the defeat of Germany in the 19141918 war. The area was later transferred to the United Nations as a trusteeship. In the struggle for independence from the colonial agents (Britain and France) in 1961, La Republique du Cameroun obtained the Bakassi peninsula in the wake of a plebiscite conducted by the UN in the trust territory. It should suffice to say that Nigeria also acquired some territories that formerly belonged to Cameroon - in a quid pro quo deal of sorts.

In a nutshell, the fundamental legal instruments on which Cameroon rested its argument and claim to Bakassi that altered the character of the peninsula and its peoples are as follows:

- The agreement between the United Kingdom and Germany signed in London on March 11, 1913.

- The Anglo-German Protocol signed in Obokun, on April 12, 1913.

- The Exchange of Letters between the British and German governments on July 6, 1914.

- The endorsement, in 1961, by both the United Nations General Assembly and the International Court of Justice, of the results of the plebiscite conducted by the Northern and Southern Cameroon on February 11 and 12,1961 ; and

- The Diplomatic note, accompanied by a map, dispatched to the government of Cameroon, in 1962 accepting the results of the plebiscites (Asobie, Nigeria-Cameroun and the Unending Conflict Over Bakassi, Nd; Mbuh 2004, pp. 5-11).

It was against the background of this brief history and legal claims of both Cameroon and Nigeria that the entire issue of the Bakassi Peninsula contro- 
versy could be understood. And, it is this narrative that informs the legal moves and counter-moves of both countries in addressing the modalities and instrumentalities for resolving the thorny issue. In spite of their legal and political posturing, the procedures for assailing such a problem are clearly outlined in the United Nations and the OAU Charters within the context of negotiation, conciliation and arbitration as discussed earlier.

\section{Negotiation, Conciliation and Arbitration under the sponsorship of the UN: the Cameroon-Nigeria Bakassi Peninsula Case}

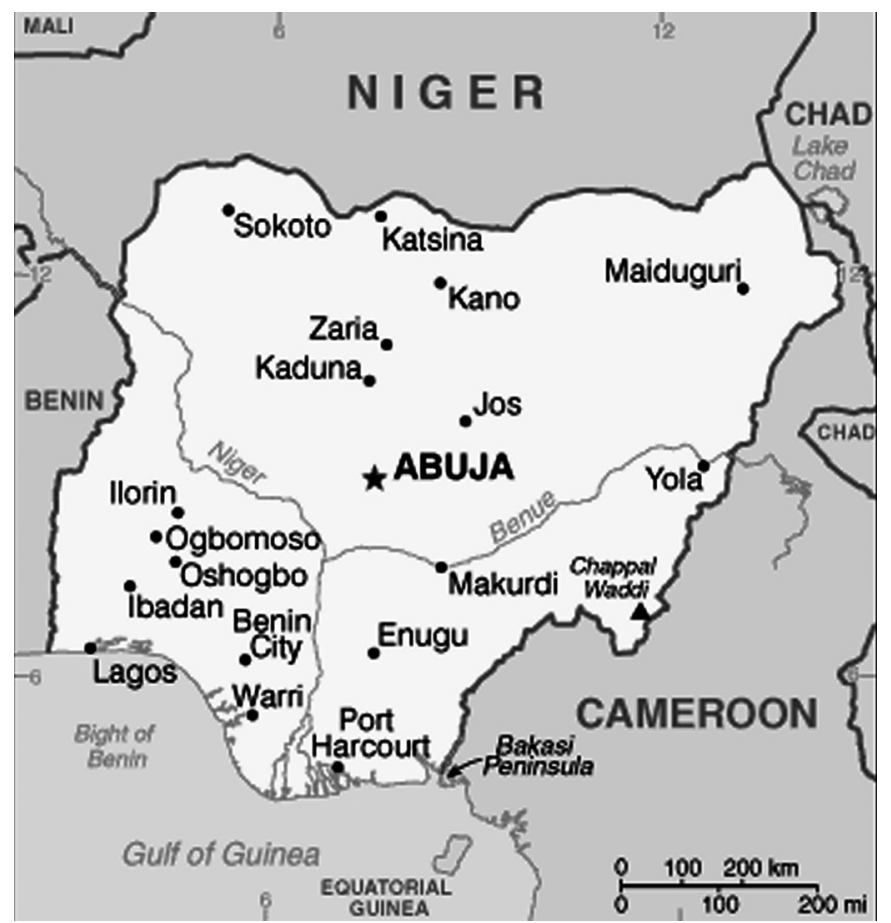

Source: Felicia Price, The Bakassi Peninsula: The Border Dispute between Nigeria and Cameroon http://64.233.169.104/search?q=cache:RJA5Epgu45sJ:www.america...

Under Pacific Settlement of Disputes, Article 33 (1) of the UN Charter states: The parties to any dispute, the continuance of which is likely to endanger the 
maintenance of international peace and security, shall, first of all, seek a solution by negotiation, enquiry, mediation, conciliation, arbitration, judicial settlement, resort to regional agencies [e.g. Economic Community of West African States and the OAU/AU, etc.] or other peaceful means of their own choice.

This provision of the UN charter outlines the strategy for a peaceful settlement of dispute by aggrieved parties generally by the application of three major strategies viz.: negotiation; conciliation - i.e. the Good Offices of the UN Secretary-General; and arbitration or judicial settlement (Anderson 2006, pp. 2-4). Such a methodical approach to resolving conflict allows the disputing parties to absorb and mollify the political emotions of political actors and citizens affected by a discrepancy. The assumption is that when negotiation and conciliation strategies between the disputants fail, arbitration technique would be applied. Article 94 (1) of the UN Charter compels conflicting parties to comply with International Court of Justice (ICJ) verdicts. And, Article 94 (2) states: If any party to a case fails to perform the obligations incumbent upon it under a judgment rendered by the Court the other party may have recourse to the Security Council, which may, if it deems necessary, make recommendations or decide upon measures to be taken to give effect to the judgment (Public International Law 2002, p. 2).

In the Bakassi Peninsula case, however, an appeal to the Security Council was averted by the Good Offices of the Secretary-General. But how did the territorial claims between Cameroon and Nigeria come to this entanglement? In their piece on "Inter-state Conflicts and Conflict resolution in the Gulf of Guinea" Osita C. Eze and Rudolf Traub-Merz provide the following summarized chronology of events leading to the arbitral phase of the territorial dispute between these (relatively) friendly neighbors:

- 14 August 1965: Nigeria accepted on sole condition of reciprocity, compulsory jurisdiction of ICJ by a unilateral declaration under Article 36 (2) of ICJ Statute;... (Yearbook of the International Court of Justice, 1993-1994, pp. 108-109).

- 21 June 1971: Nigeria/Cameroon Joint Boundary Commission signed at Lagos a Declaration setting out geographical coordinates for 20 points on maritime boundary to a distance of 17.7 nautical miles seaward of the line linking Sandy Point and Tom Shot Point;

- 28 January 1972: Announcement that the Federal Military Government [of Nigeria] had repudiated the above declaration;

- 1 September 1974: Heads of state of Nigeria and Cameroon signed a Declaration at Kano establishing a corridor of "freedom from oil prospecting" in Cross/Calabar estuary; 
- 3 March 1994: Cameroon accepted compulsory jurisdiction of ICJ by a unilateral declaration; (Yearbook of the International Court of Justice 1993-1994, p. 87).

- 29 March 1994: Cameroon filed application dated 28th March 1994 to the ICJ re Bakassi and maritime boundary;

- 6 June 1994: Cameroon filed additional application to the ICJ re Lake Chad area (Eze and Traub-Merz 2004, pp. 78-79).

Overall, the list of issues brought before the ICJ in the Cameroon-Nigeria boundary dispute were: 1 . Lake Chad; 2 . the land boundary between Nigeria and Cameroon; 3. Bakassi; 4. Cameroon's claim to a major share of offshore resources - particularly oil in the Gulf of Guinea; and 5. claims of both sides for reparations involving state responsibilities (Embassy of the Federal Republic of Nigeria 2007, p. 2).

But the real bone of contention regarding the case filed in the ICJ by Cameroon against Nigeria concerned the dispute over the question of sovereignty in the oil-rich Bakassi Peninsula (International Court of Justice Press Release 2002, pp. 1-24) since the mechanisms for resolving some of the other issues had been in place - e.g., the Lake Chad Basin Commission. In the CameroonNigeria contestation on the Bakassi Peninsula issue, Nigeria grounded her claims to the area thus:

In 1884, the Kings, Chiefs and People of Old Calabar signed a treaty of protection with Great Britain. That treaty did not give the British power to alienate all or any part of the land which they were supposed to protect. The protectorate included Bakassi. This is what they claimed to have done in 1913 when Great Britain allegedly ceded Bakassi to Germany. The Court, in disregard of the inalienable rights of the Kings, Chiefs and people of the old Calabar to their land and ancestral homes, upheld the Anglo-German Treaty of 1913 by which Britain ceded Bakassi Peninsula to Germany. This treaty was essentially the basis of the judgment giving sovereignty over Bakassi to Cameroon. The Court without any justification whatsoever failed or refused to follow its own precedent set in the Advisory Opinion on Western Sahara where it recognized the local rulers' possession and title as superior to other forms of title (Embassy of the Federal Republic of Nigeria 2002, p. 2).

Another argument on this case as it applies to the roles of the Kings, Chiefs, and their subjects on this matter may rest on the assumption that the rulers having "signed" a treaty of protection with the colonial powers gave away their "rights" to the colonial hegemonies - Britain and Germany. Thus, consulting with the British and German colonial subjects (including the Chiefs and Kings) in the contested areas was at that time irrelevant to these alien powers. Nevertheless, Nigeria countered the preceding notion and contention by stating that: 
In the case of Bakassi, the root of title belongs to the Kings, the Chiefs and the people of Old Calabar. Neither Germany nor for that matter Cameroon could therefore claim Bakassi as terrae nullius. In the judgment in the case of the frontier dispute, Burkina Faso-Mali which the Court relied upon in the Nigeria vs. Cameroon judgment, the [Court] interpreted the first part of that paragraph (i.e. paragraph 63 of the case) as being in favor of Cameroon but failed to take cognizance of the latter part of the paragraph which states that effectivites must invariably be given consideration. The Court failed to give that consideration (Embassy of the Federal Republic of Nigeria 2002, p. 2).

\section{Decision of the ICJ and Some Political and Economic Considerations}

A summary of the 150 page decision reached by the ICJ concerning the Land and Maritime Boundary between Cameroon and Nigeria case was presented at a press conference by President Guillaume at The Hague on October 10, 2002 thus:

The Court first decided that the land boundary between the two countries had been fixed by treaties entered into during the colonial period and it upheld the validity of those treaties. It moreover rejected the theory of historical consolidation put forward by Nigeria and accordingly refused to take into account the effectivites relied upon by Nigeria. It ruled that, in the absence of acquiescence by Cameroon, these effectivites could not prevail over Cameroon's conventional titles. Accordingly, the Court decided that, pursuant to the Anglo-German Agreement of 11 March 1913, sovereignty over Bakassi lies with Cameroon...

The Court further decided that Cameroon, for its part, is under an obligation expeditiously and without condition to withdraw any administration or military or police forces which may be present on Nigerian territory along the land boundary between Lake Chad and Bakassi. Nigeria bears the same obligation in respect of any territory in this sector which falls within the sovereignty of Cameroon...

The Court rejected Cameroon's submissions seeking to have Nigeria ordered to repair the injury suffered by Cameroon, in particular as a result of the occupation of Bakassi. In this respect, the Court noted that Cameroon had secured recognition of its sovereignty over the peninsula and the disputed area of Lake Chad. It found that the injury suffered by Cameroon by reason of the Nigerian occupation was sufficiently addressed by the very fact of that recognition and of the evacuation of those territories (International Court of Justice, Nd.) ...

In brief, the ICJ, to the chagrin of Nigeria, noted in its verdict that the land boundaries between Nigeria and Cameroon had been established by treaties signed by Britain and Germany and accepted the authenticity of those treaties. It further rejected the "theory of historical consolidation [involving the Kings, Chiefs and subjects who had lived under the jurisdiction of Nigeria] put for- 
ward by Nigeria and accordingly refused to take into account the [effectivites] relied upon by Nigeria (International Court of Justice Press Release 2002, pp. 1-24)." Arguably, the rationale for the lukewarm attitude toward the rulings of the Court by Nigeria has, in part, some political undertones. This argument is plausible to the extent that Cameroon and Nigeria declared under Article 36 (2) of the Statute of the ICJ that they would accede to the judgment of the Court in the boundary disputes. Indeed, the ICJ rulings are considered final and disputants are obliged to abide by the verdicts under provisions of Article 60 of the Statute (Public International Law 2002, p. 3). For Nigeria, politically, it is stated constitutionally that,

All land and territory comprising the nation of Nigeria is specified in the Constitution of the Federal Republic of Nigeria 1999. Bakassi as a local Government is so specified in Part I of the first Schedule of the Constitution. Being a nation ruled by law, we are bound to continue to exercise jurisdiction over these areas in accordance with the Constitution. The responsibility for the amendment of the Constitution being that of the National Assembly of Nigeria and the State Governments and Local Government Councils will continue to exercise their constitutional responsibilities over all of the Nigerian territory as specified in the Constitution until the National and various States Assemblies effect amendment to the Constitution (Embassy of the Federal Republic of Nigeria 2002, p. 3).

For Cameroon, particularly Anglophone Western Cameroon, the annexation of the oil-rich Bakassi peninsula may strengthen the argument of those advocating independence from Yaoundé and the Francophone speaking part of the country (sometimes referred to as Eastern Cameroon). Some Anglophone elites have often argued politically and economically that in spite of their territory generating wealth from oil proceeds for La Republic du Cameroun, their minority status has often led to their marginalization in terms of development projects and lucrative jobs in government. Moreover, they lack political clout vis-à-vis their dominant Francophone compatriots (Bayart 1978, pp. 82-99; Udogu 2001, p. 29).

The economic and political factors aside, the New York Times reported that overall the outcome was theoretically a variable-sum-game of sorts. In fact, Marc Lacey and Neela Banerjee noted that "Cameroon did not get all it was seeking. The Court awarded other disputed parcels along the border to Nigeria and ordered each country to pull troops from land handed over to the other. The Court rejected Cameroon's requests for compensation from Nigeria for its long occupation of the peninsula, saying that giving the land to Cameroon resolved the matter" (Lacey and Banerje 2002, p. 3). 


\section{Implementation of the ICJ Ruling}

It was quite impressive that giving the UN and its agencies record of passing resolutions that are often difficult to implement the ICJ's judgment on this case was embraced by both parties. Nevertheless, in order to enforce such a sensitive ruling of the ICJ on Cameroon and Nigeria there was need for the involvement and participation of an effective interlocutor - in this case, the UN Secretary-General, Kofi Annan, and his Good Offices served to bring the countries together. That Abuja and Yaoundé were amenable to carrying out the decisions of the ICJ was not in doubt given the relative rapport between Presidents Biya of Cameroon and Obasanjo of Nigeria fostered by Kofi Annan, the Secretary-General of the UN. Thus, Cameroon and Nigeria were able to come up with the modality for implementing the Court's rulings. The framework was found in the formation of the Cameroon-Nigeria Mixed Commission that was headed by Ahmedou Ould-Abdallah, the SecretaryGeneral's special envoy on this issue. He was joined by two distinguished representatives - Amadou Ali, Senior Minister of Justice of Cameroon and Prince Bola Ajibola, former Minister of Justice of Nigeria.

The Cameroon-Nigeria Mixed Commission was charged with the following tasks:

- The demarcation of the land boundary between the two countries;

- The withdrawal of civil administration, military and police forces and transfer of authority in relevant areas along the boundary;

- The eventual demilitarization of the Bakassi peninsula;

- The need to protect the rights of the affected populations in both countries;

- The development of projects to promote joint economic ventures and cross-border co-operations; and

- The reactivation of the Lake Chad Basin Commission (United Nations Office for West Africa, Nd., pp. 2-3).

In general, the Mixed Commission was able to achieve some successes in many areas of its stated objectives while transferring the thornier issues to the heads of government of Cameroon and Nigeria and the Good Offices of the Secretary-General. The commission not only identified areas in which cross-border cooperation could be promoted but also identified areas in which joint economic cooperation could be beneficial to citizens in both areas (United Nations Office for West Africa, Nd., pp. 3-4). 


\section{Conclusion}

This study is an attempt at bringing to the fore an area of African studies that is inadequately explored in political science literature. Aside from arguing that African states have always had at least a modicum of the practice of international law before the advent of colonialism, it also emphasized the extent to which African states have embraced international instruments in post-independence Africa for conflict resolution. In truth, African post-colonial states have experienced virulent intra- and inter- states conflicts as was the case in post-Westphalia Europe. In Africa, however, the conflict has often centered on the competition to capture power and control of natural resources - gold, diamond, chromium, cooper, crude oil, etc. In spite of the outcome of some of the major conflicts, African states have often looked up to the international legal system and laws to resolve their conflicts peacefully. The CameroonNigeria Bakassi peninsula dispute that employed the instrumentalities of negotiation, conciliation and arbitration techniques in solving a potentially explosive territorial conflict is a case in point. Such a development should be embraced and emulated by policy makers within the objectives of the contemporary African Union that stresses, inter alia, the vision of Africa's revival within the context of greater social, economic and political unity in the millennium (Udogu 2007, pp. 28-31). In this endeavor, the importance of civil society organizations in advancing such a vision is imperative (Udogu 2007, pp. 1, 121, 141). In all, this study brings to the limelight the extent to which African states are increasingly relying on international law, the AU and the Good Offices of the UN and its various agencies - particularly the ICJ to resolve international boundary conflicts. It is possible that this approach to ameliorating African disputes could serve as a model for the continent in this century.

\section{References}

Ajala, Adekunle. 1973. Pan-Africanism: Evolution, Progress and Prospects. New York: St. Martin's Press.

Anderson, David. 2006. "Methods of Resolving Maritime Boundary Dispute." International Law Discussion Group at Chathan House, February 14.

Asobie, Assisi. ND. "Nigeria-Cameroun and the Unending Conflict Over Bakassi." http://www. nigerdeltacongress.com/narticles/nigeria_cameroun_and...

Banks, Arthur S (ed.). 1977. Political Handbook of the World: 1984-1985. New York: McGraw Hill Book Company.

Bayart, J. F. 1978. "The Neutralization of Anglophone Cameroon,” in R. A. Joseph (ed.), Gaulist Africa: Cameroon under Ahmadu Ahidjo. Enugu, Nigeria: Fourth Dimension Press. 
Boutros-Ghali, Boutros. 1972. Les Conflict de Frontier en Afrique. Paris: Edition Technique Economiques.

Bovill, Edward W. 1958. The Golden Trade of the Moors. Oxford: Oxford University Press.

Brierly, J. L. 1963. The Laws of Nations: An Introduction to the International Law of Peace. Oxford: Oxford University Press.

Critical International Law: Recent Trends in the Theory of International Law. 1990. The Debt of International Law to Liberal Political Theory http://www.ejil.org/journal/Vol2/No1/art403.htm\#TopOFPage.

El-Ayouty (ed.). 1975. The Organization of African Unity after Ten Years: Comparative Perspective. New York: Praeger Inc.

Elias, T. O. 1972. Africa and the Development of International Law. New York: Oceana Publications, Inc.

Embassy of the Federal Republic of Nigeria. 2002. "Nigeria's Reaction to the Judgment of the International Court of Justice at the Hague.” Nigeria Information Service Center. http:// 72.14.203.104/search?+cache:cOxq1vHbaYj.

Eze Osita C. and Rudolf Traub-Merz. 2004. "Inter-state conflicts and Conflict Resolution in the Gulf of Guinea," in Rudolf Traub-Merz and Douglas Yates (eds.), Oil Policy in the Gulf of Guinea: Security and Conflict, Economic Growth, Social Development. Yaounde, Cameroon: Friedrich-Ebert-Stiftung Publishers.

International Court of Justice Press Release. 2002. "Land and Maritime Boundary between Cameroon and Nigeria (Cameroon V. Nigeria: Equitorial Guinea Intervening): Summary of the Judgment 10 October, pp. 1-24. http://72.14.203.104/search?q=cache:kWozKABNZMO.

Jacobini, H. B. 1968. International Law: A Text. Homewood, IL: The Dorsey Press.

July, Robert W. 1992. A History of African People 4th edition. Prospect Heights, IL: Waveland Press.

Kennedy, D. 1987. International Legal Structure. Baden-Baden: Nomos Verlagsgesellschaft.

Lacey, Marc and Banerje, Neela. 2002. "World Court Rules for Cameroon in Prolonged Oil Land Border Dispute with Nigeria.” New York Times, October 11, p. 3. http://72.14.203.104/ search?q=cache:.JS6NTGXvUj.

Legum, Colin. 1975. “The Organization of African Unity Success or Failure?” International Affairs, Vol. 51, pp 208-219.

Lorca, Arnulf B. 2006. "International Law in Latin America or Latin American International Law? Rise Fall, and Retrieval of a Tradition or Legal Thinking and Political Imagination." Harvard International Law Journal, Vol. 47, No. 1, pp. 283-305.

Louis, W. Roger et al. 1971. France and Britain in Africa. New Haven, CT: Yale University Press.

Lumumba-Kasongo, Tukumbi. 2004. "Rethinking Pan-Africanism in the Search for Social Progress.” Global Dialogue, Vol. 6, No. 3-4, pp. 62-72.

MacIntyre, A. 1985. After Virtue: A Study of Moral Theory (2nd edition). Notre Dame, IN: University of Notre Dame Press.

Mbuh, Muluh. 2004. “The Bakassi Peninsula Dispute.” International Law and Conflicts: Resolving Border and Sovereignty Disputes in Africa. http://www.postwatchmagazine.com/.

Meyers, B. David. 1974. "Interregional Conflict Management by the Organization of African Unity.” International Organization, Vol. 28, pp. 345-373.

$O A U$ Charter \& Rule of Procedure. 1982. Addis Ababa, Ethiopia: Division of Press and Information.

Parkinson, F. 1975. "Pre-colonial International Law" in A. K. Mensah-Braown (ed.), African International Legal History. New York: United Nations Institute for Training and Research.

Protocol of the Commission on Mediation, Conciliation and Arbitration. 1964. International Legal Material, Vol. 3, pp. 1116-1124. 
Public International Law News. 2002. Freshfiel Bruchhaus Deringer 16, December. http://www. spr-consilio.com/artpi11.htm.

Shaw, Timothy M. and Ojo Sola (eds.). 1982. Africa and the International Political System. Lanham, MD: University Press of America.

Smith, William E. 1987. "Chad: War by Proxy in the Dunes." Time, Vol. 129, No. 3, p. 37.

Tucker, R. W. (ed.). 1966. Principles of International Law. New York: Holt Rinehart and Winston Inc.

Udogu, E. Ike. 2001. "Ethnicity and Theory in African Politics," in E. Ike Udogu (ed.), The Issue of Political Ethnicity in Africa. Aldershot, UK: Ashgate Publishing Company.

- 2003. "National Constitutions and Human Rights Issues in Africa." African and Asian Studies, Vol. 2, No. 2, pp. 101-123.

—. 2007. African Renaissance in the Millennium: The Political, Social and Economic Discourses on the Way Forward. Lanham, MD: Lexington Books.

United Nations Office for West Africa. ND. "Cameroon-Nigeria Mixed Commission-Background." http://72.14.203.104/search?q=cache:K46qe5-mmeUJ.

Wallace-Bruce, Lante. 1985. "Africa and International Law - The Emergence of Statehood." The Journal of Modern African Studies, Vol. 23, No. 4, pp. 575-602.

Yearbook of the International Court of Justice. 1993/4. Hague: UN Publication. 

Copyright of African \& Asian Studies is the property of Brill Academic Publishers and its content may not be copied or emailed to multiple sites or posted to a listserv without the copyright holder's express written permission. However, users may print, download, or email articles for individual use. 